\title{
In-situ Young's Moduli of the Constitutive Layers in a Solid Oxide Fuel Cell
}

Amit Pandey ${ }^{\dagger, 1,2}$, Amit Shyam ${ }^{1}$, Zhien Liu $^{2}$ and Richard Goettler ${ }^{2}$

${ }^{1}$ Materials Science and Technology Division, Oak Ridge National Laboratory, Oak Ridge, TN 37831, USA

2,* LG Fuel Cell Systems Inc., North Canton, OH - 44720, USA

\footnotetext{
${ }^{\dagger}$ Current Address, Author to whom all correspondence should be addressed. e-mail: dramitpandey@gmail.com, amit.pandey@lgfcs.com
} 


\begin{abstract}
In-situ Young's moduli of thin constituent layers of a solid oxide fuel cell (SOFC) are needed to estimate the mechanical reliability of the fuel cell unit. Because a robust technique to measure the same is not available, an improved methodology is proposed to determine the in-situ Young's moduli of thin ceramic layers of a substrate-supported SOFC. The measured Young's moduli of the constituent layers were found to be close to those of corresponding bulk materials using the resonant ultrasound spectroscopy (RUS) technique but were different from the values obtained using nanoindentation.
\end{abstract}

Keywords: Tension, Porosity, Microcracking, Elastic modulus, Reliability. 


\section{INTRODUCTION}

Solid oxide fuel cells (SOFCs) are environmentally clean, high efficiency functional devices that transform chemical energy stored in fuel into electrical energy [1-4]. An SOFC can be structurally viewed as a multilayer ceramic composite system that operates at elevated temperature. The individual ceramic layers in the SOFC contain a multitude of microstructural features (e.g. pores, microcracks, phase boundaries etc.), which play an important role in the functional, transport [5-6] and mechanical response [7-11] of the cell. For example, an increase in porosity in an electrochemically active layer could lead to a voltage drop [12], decrease in electrolyte temperature [5] and activation overpotential [13] and may lead to structural failure as a result of the degradation of Young's moduli of thin constituent layers [5, 14]. The Young's modulus is used to calculate the hotspot failure stresses that are generated as a result of thermal gradients across the ceramic layer [15-18]. The Young's modulus is also required to determine the residual stresses that develop in the individual layers as the SOFC is cooled from the processing temperature and subsequently heated back to the operation temperature [15, 20-23]. A robust technique to measure the Young's moduli of the constituent layers will, therefore, be beneficial for the mechanical design, reliability and safe operation of SOFCs.

The nanoindentation technique is most frequently used to obtain the Young's modulus of thin ceramic materials $[19,24-25]$. For specimens with high defect densities, however, the material properties obtained from the nanoindentation technique are often unreliable because they constitute the local instead of the bulk response of the material [26]. At the same time, insitu elastic properties of multilayer systems such as SOFCs and thermal barrier coatings (TBCs) [27] have proven to be difficult to measure experimentally, owing to the reduced dimensionality of the individual layers. In the present investigation, an improved experimental methodology for 
determination of the Young's modulus of multilayer materials is proposed. The current methodology consists of

1. Fabrication of a series of specimens with increasing number of constituent layers that are screen-printed on a porous ceramic substrate.

2. Microtensile testing of individual bi- and multilayer specimens under ambient conditions.

3. Measurement of in-plane strain on both sides (substrate and outermost functional layer side) of the specimen during tensile deformation by application of a noncontact digital image correlation (DIC) technique.

4. Calculation of the Young's modulus of each thin ceramic constituent layer in a substrate supported SOFC design by applying the equistrain criterion.

The above approach also allowed identification of the validity limit of the equistrain criterion. The Young's modulus values of individual thin ceramic layers determined with the proposed methodology are compared with measurements performed on similar materials with nanoindentation and with bulk specimens using the resonant ultrasound spectroscopy (RUS) technique.

\section{EXPERIMENTAL METHODOLOGY}

\subsection{SPECIMEN PREPARATION: MULTILAYER CERAMIC SPECIMENS}

SOFC samples were manufactured by LG Fuel Cell Systems Inc. (LGFCS). Unlike an anode supported SOFC [28], the structural support, in this case, is provided by a rectangular thick wall $(<1 \mathrm{~mm})$ MMA (magnesia-magnesium aluminate spinel) extruded substrate with 
longitudinal channels for fuel flow (Figure 1). Functional layers were screen-printed in a sequential manner onto the MMA substrate, starting from the porous anode barrier (PAB). Additional functional layers that were screen printed on the substrate in sequence included the anode current collector (ACC), anode (A), electrolyte (E), cathode (C), and cathode current collector (CCC). This sequential screen printing led to six different types of multilayer samples; each with different number of functional layers (Table 1). Microtensile specimens were fabricated from the substrate and multilayer samples using a series of dry cutting and grinding procedures described elsewhere [29-30]. Some multilayer specimens had a curvature prior to cutting and the grinding process reduced the specimen curvature, presumably due to residual stress relief as a result of the grinding operation. In these multilayer samples, grinding was always performed on the substrate side, thereby preserving the thickness and integrity of the functional layers. Further, in the multilayer samples, the microtensile specimens were fabricated from the active area of the fuel cell such that the layers were all continuous in the plane of the specimens. Microtensile beam specimens were prepared to a rectangular test geometry with a total average thickness of $0.190 \pm 0.002 \mathrm{~mm}$, gage length of $6 \pm 2 \mathrm{~mm}$ and gage width of $2 \pm$ $0.01 \mathrm{~mm}$ (Table 1). In addition, MMA substrate specimens with various thickness values (190, 150 , and $100 \mu \mathrm{m})$ were prepared for microtensile testing and dimensions of the specimens were measured optically prior to the testing using a Nikon profile projector (V-12).

\subsection{MICROSTRUCTRE AND TESTING PROCEDURE}

The microstructure of these materials was characterized using a Hitachi S-4800 Field Emission scanning electron microscope (SEM). Uniaxial tensile experiments were conducted on the MMA substrate and on all multilayer ceramic specimens using a microtesting system described 
elsewhere [7]. Specimens were glued at both ends of the tensile fixture and were deformed at a displacement rate of $10^{-3} \mathrm{~mm} / \mathrm{sec}$. Images of the gage section were captured at a rate of $1 / \mathrm{sec}$ using a high-resolution CMOS camera and strains were calculated with the digital image correlation (DIC) technique using a Matlab®-based code described elsewhere [7, 31- 32]. A grid of approximately 25000 virtual markers was defined and each marker subset was $20 \times 20$ pixels $^{2}$. Due to the rectangular geometry associated with the gage section of the microtensile specimens, some specimens failed at the glued region-gage section interface.

Resonant ultrasound spectroscopy (RUS) was applied to measure the elastic modulus of disk shaped MMA specimens (thickness $\sim 0.70 \mathrm{~mm}$ and diameter $\sim 31.8 \mathrm{~mm}$ ). RUS was also performed on anode, electrolyte, cathode and cathode current collector with specimens that were powder pressed, sintered for $1 \mathrm{hr}$ at $1380{ }^{\circ} \mathrm{C}$ and then machined into disks (thickness $\sim 1.5 \mathrm{~mm}$ and diameter $\sim 25 \mathrm{~mm}$ ). Nanoindentation experiments were performed to an indentation depth of $250 \mathrm{~nm}$ using a Hysitron Triboindentor ${ }^{\mathrm{TM}}$ with a Berkovich tip on the ceramographically prepared cross-section of the SOFC sample. A total of 15 indentations were made in each SOFC layer, and average values of reduced modulus [33] are reported.

\section{RESULTS AND DISCUSSION}

\subsection{MICROSTRUCTURE}

Figure 2 shows an SEM micrograph of the cross-section of a substrate supported SOFC design that was imaged using backscattered electrons. The functional layers along with their individual average thickness values (in the range 7 to $70 \mu \mathrm{m}$ ) are identified in Figure 2. Each layer in Figure 2 exhibited varying levels of porosity, with the electrolyte exhibiting the lowest 
level of porosity. The microstructure of the substrate consists of a porous composite of cubic magnesium oxide $(\mathrm{MgO})$ and spinel $\left(\mathrm{MgAl}_{2} \mathrm{O}_{4}\right)$ phases. In addition, the substrate also contained an appreciable density of engineered defects (microcracks and porosity) that facilitate the functional requirement of fuel flow across the thickness of the substrate. Microcracking in the MMA substrate is a result of thermal strain mismatch between the two cubic phases during cooling from the processing temperature and the microcracks are, therefore, referred to as thermally induced microcracks [7]. The cell structure consists of multiple layers: the YSZ (yttriastabilized zirconia), porous anode barrier ( $\mathrm{PAB}$ ), a cermet anode current collector, the active anode, a ScSZ electrolyte, LSM (lanthanum strontium manganate)-YSZ based cathode and an LSM-based cathode current collector. It is noted that the unit cell structure of the SOFC has a functionally graded structure with varying thickness, microstructure and density. This design is engineered to compensate the thermal and mechanical mismatches arising from the differences in thermal expansion and elastic modulus between the adjacent layers while achieving the required electrochemical performance.

\subsection{UNIAXIAL TENSILE RESPONSE: MMA SUBSTRATE SPECIMENS}

Two sets of uniaxial tensile experiments were conducted, which included monotonic loading (190 $\mu \mathrm{m}$ thick, Figure 3a) and loading-unloading-reloading (for 190 and $100 \mu \mathrm{m}$ thick specimens, Figure 3b). These experiments were conducted to study the effect of specimen thickness on the stress-strain response and to decouple anelastic (recoverable) and inelastic (irrecoverable) strains at various stress levels. The stress-strain response of the specimen can be a function of the specimen thickness due to the fact that the employed grinding procedure affects the response of thinner specimens more than the thicker specimens. Observations from such 
load-unload-reload experiments are used to determine the stress value beyond which pre-existing microcracks start to propagate [7, 10-11]. Figure 3a shows the uniaxial tensile response of MMA substrate (190 $\mu \mathrm{m}$ thick) from three separate tests and the average failure stress and strain were $9.5 \pm 0.2 \mathrm{MPa}$ and $0.032 \pm 0.005 \%$, respectively. Unlike conventional structural ceramics, tensile response of the MMA substrate is non-linear, which implies that the apparent modulus becomes a function of stress or strain [7]. This non-linear tensile response of porous microcracked ceramic materials is dictated by the pre-existing microcracks and their evolution during loading [7].

The loading-unloading-reloading response for 190 and $100 \mu \mathrm{m}$ thick specimens of MMA substrate are shown in Figure 3b. Unloading was conducted from five different stress levels (2.5, 5, 7, 8 and $9 \mathrm{MPa}$ ) and the corresponding residual strain was obtained at zero load. It was found that a) the unloading tensile response remained non-linear, b) unloading below a stress level of $\sim 5 \mathrm{MPa}$ resulted in zero residual strains (i.e. no inelastic response), c) initial Young's moduli (for stress- strain curve up to $2.5 \mathrm{MPa}$ ) for 190 and $100 \mu \mathrm{m}$ thick specimens are 71.1 and $69.0 \mathrm{GPa}$ and d) the stress- strain response of $150 \mu \mathrm{m}$ thick specimen (not shown) lies in between 190 and $100 \mu \mathrm{m}$ thick specimens. At the same time, all unloading beyond a stress level of $\sim 5 \mathrm{MPa}$ led to non-zero, positive, residual inelastic strains and increased residual strains with an increase in maximum stress. An anelastic response (recoverable strain) is due to opening and closure of the thermally induced microcracks and frictional sliding of irregular crack faces [7]. The inelastic response (irrecoverable strain), however, is an indicator of the permanent damage in the material and could arise from the extension of thermally induced microcracks and/or newly generated microcracks during loading. The microcracks that cause permanent deformation are referred to as mechanically induced microcracks. Based on the above observations and a recent study on 
similar materials by Pandey et al., [7], it can be concluded that loading beyond 4-5 MPa would introduce irrecoverable damage in the MMA substrate material and this damage is responsible for a further increase in non-linearity and decrease in the slope of the stress-strain curve.

\subsection{UNIAXIAL TENSILE RESPONSE: MULTILAYER CERAMIC SPECIMENS}

Table 2 presents an overview of existing experimental techniques, which have been applied to study the elastic properties of multilayer (composites, coatings, thin films etc.) specimens. A review of the literature suggests that there are few established techniques available to measure the in-situ elastic properties of multilayer (more than 3 layers) ceramic materials. At the same time, existing techniques for testing multilayer specimens are not readily applicable for specimens with porous ceramic layers. For example, for porous ceramic specimens the widely used beam bending experiment has limitations, such as crushing at contact points. The corresponding theory for flexural testing of specimens with more than three layers could be complex [34]. At the same time, for porous materials, the flexure strength is found to be in between the tensile and compressive strength with tensile strength being the lowest [35]. A relevant technique for Young's modulus measurement of individual layers in multilayer specimens is based on measurement of curvature change with deposition of multilayers [48-49]. The curvature technique, however, would also require polishing/grinding of the thick substrate, since the sensitivity of displacement to deposition stress is directly proportional to the substrate length and inversely proportional to square of substrate thickness [45]. The feasibility of this technique was verified by using the Stoney formula [48] on the bilayer beam (Figure 4a). It was found that a $20 \mathrm{MPa}$ residual stress (which is close to the tensile failure stress) with a $5 \mathrm{~mm}$ thick substrate results in an output beam radius of $\sim 680 \mathrm{~m}$ and the corresponding curvature 
measurement would be beyond the measurement capability of available instrumentation [46]. A recent paper by Araki et al. [47] have used a combination of finite element (FE) and RUS technique to determine the elastic properties of the electrolyte. However, the use of this technique is limited by the number of layers in the multilayer specimen and the corresponding analysis gets complicated for more than 3 layers.

Uniaxial tensile testing tests were performed on the multilayer ceramic specimens with the layers parallel to the loading axis. This loading scheme qualified the use of equistrain condition $[36,50]$ to calculate the elastic modulus of each individual layer that forms the composite. Figure 4a-f shows the uniaxial tensile stress-strain curves of multiple ceramic layers, starting from a simpler bilayer specimen (Figure 4a) to multilayer specimens (Figures $4 \mathrm{~b}-\mathrm{f}$ ). It is mentioned here that for each multilayer ceramic specimen, strains on all tensile specimens were measured in the gage section on both planes (i.e. both sides, the MMA substrate and the outermost functional layer) in at least two separate tests. This is illustrated in Figure 4b-f, where each plot shows at least two sets of stress-strain curves for each type of multilayer specimen. In Figure 4, the solid symbols and markers are chosen for corresponding stress-strain curves, where imaging and inplane strain calculations were performed on the MMA substrate and the outermost layer, respectively. Based on the stress-strain response presented in Figures 3-4, the following observations can be made:

1. Similar to the MMA substrate alone (Figure 3), the tensile stress-strain response of bi- and multilayer ceramic specimens are non-linear (Figure 4a- f).

2. The average failure stress and strain of multilayer ceramic specimens (Figure 4a- f) is higher when compared to corresponding values for the MMA substrate specimen $\left(\sigma_{\mathrm{f}} \sim 10 \mathrm{MPa}\right.$ and $\left.\varepsilon_{\mathrm{f}} \sim 0.03 \%\right)$. 
3. Failure stresses for specimens in Figure $4 \mathrm{a}-\mathrm{c}$ are lower $\left(\sigma_{\mathrm{f}} \sim 20 \mathrm{MPa}\right.$ and $\left.\varepsilon_{\mathrm{f}} \sim 0.06 \%\right)$ as compared to specimens in Figure $4 \mathrm{~d}-\mathrm{f}\left(\sigma_{\mathrm{f}} \sim 30 \mathrm{MPa}\right.$ and $\left.\varepsilon_{\mathrm{f}} \sim 0.06 \%\right)$, that is, the specimens that included the dense electrolyte layer.

4. For multilayer ceramic specimens, the stress-strain curves (Figure 4a- f) of the MMA substrate and outermost layer overlap at lower values of stresses. The two stress-strain curves, however, start to deviate for stresses beyond 3-5 MPa.

5. When the applied stress exceeds $\sim 3 \mathrm{MPa}$, the in-plane strain on MMA substrate is lower than the corresponding strain in the outermost layer for the same value of stress, and the difference between the two strain values increases with loading. This result is consistent for Figures 4a- f.

The above experimental observations suggest that the equistrain assumption is applicable only for stresses lower than $\sim 3 \mathrm{MPa}$. In other words, the strain in all layers is the same for applied stresses less than $3 \mathrm{MPa}$. The invalidity of the equistrain assumption at higher stresses could be explained based on the results discussed in Section 4.2, where initiation of mechanically induced microcracks (or residual inelastic strains) started at $3 \mathrm{MPa}$ and further loading led to permanent damage in the MMA substrate and most likely propagated into other layers. The permanent damage could result in the initiation of strain incompatibility between the substrate and additional layers, thereby limiting the validity of the equistrain assumption. It is known that [50] an equistrain assumption does not hold true if there is interfacial sliding between layers and the latter can be enhanced by mechanically induced cracking in the substrate. In addition, strength of multilayer ceramic specimens could be affected by residual stresses in the layers [5152] and therefore, addition of extra layers could enhance the failure stresses as compared to the strength of MMA substrate specimens. 
With the above discussion, a new experimental methodology is proposed which was applied to measure the in-situ Young's modulus of thin ceramic layers in the SOFC. This methodology can be used for multilayer systems where a series of specimens could be fabricated, as mentioned in Section 2. The Young's modulus of each ceramic layer is calculated from tensile stress-strain response of the MMA substrate and multilayer ceramic specimens and is discussed in the next section.

\subsection{ESTIMATE OF IN-SITU YOUNG'S MODULUS}

In the present investigation, the Young's modulus was determined using a 20 microstrain $(\mu \varepsilon)$ deviation from linearity criterion in the stress-strain curve. The $20 \mu \varepsilon$ deviation from linearity definition (or the initial tangent modulus) was used based on the following considerations:

1) A $20 \mu \varepsilon$ strain deviation from linearity criterion allowed the use of the stress- strain curve below a stress value of $\sim 3 \mathrm{MPa}$ in all cases thereby, ensuring the validity of equistrain criterion. This criterion can, therefore, be applied to determine the tensile elastic response of the MMA substrate (Figure 3a) and multilayer ceramic specimens (Figure 4a-f).

2) In the case of the MMA substrate, this definition yields a Young's modulus value of $70 \pm$ $1 \mathrm{GPa}$ (Figure 3a), which was close to the value obtained using the resonant ultrasound spectroscopy (RUS) technique (72 $\pm 2 \mathrm{GPa})$. Values of Young's modulus obtained from a static technique (uniaxial tension) and dynamic (RUS) technique are similar for lower loads. A similar observation has been reported for other porous and microcracked ceramic materials $[7,40,55]$. 
The average Young's modulus of composite multilayer specimens was determined from all corresponding stress-strain curves (Figure 4a-f) as listed in Table 1 according to the $20 \mu \varepsilon$ deviation from linearity definition. The equistrain criterion was later used on the stress- strain curve below $~ 3 \mathrm{MPa}$ to determine the Young's modulus of individual layers according to the procedure outlined below

- For a $190 \mu \mathrm{m}$ thick bilayer (MMA substrate and PAB) specimen, the average thicknesses of MMA substrate and PAB layer were $165 \mu \mathrm{m}\left(\mathrm{t}_{1}\right)$ and $25 \mu \mathrm{m}\left(\mathrm{t}_{2}\right)$, respectively. The 20 $\mu \varepsilon$ deviation from linearity definition, in the stress-strain curve, (Figure 4a) led to a Young's modulus of the multilayer composite (with thickness, $t=t_{1}+t_{2}=190 \mu \mathrm{m}$ ) of $69.5 \pm 2.0 \mathrm{GPa}$. Now, applying the equistrain criterion, the Young's modulus of the PAB material $\left(\mathrm{E}_{\mathrm{PAB}}\right)$ can be calculated as:

$$
\begin{gathered}
\mathrm{E}_{\text {bilayer }}=\left(\mathrm{t}_{1} / \mathrm{t}\right) \mathrm{E}_{\text {Substrate }}+\left(\mathrm{t}_{2} / \mathrm{t}\right) \mathrm{E}_{\mathrm{PAB}}=69.5 \mathrm{GPa} \\
\mathrm{E}_{\mathrm{PAB}}=66.2 \mathrm{GPa}
\end{gathered}
$$

- This procedure was repeated for each of the other multilayer specimens. Finally, for a $190 \mu \mathrm{m}$ thick seven layer specimen, the average thickness of MMA Substrate, PAB, ACC, Anode, Electrolyte, Cathode and CCC layers were $43 \mu \mathrm{m}, 25 \mu \mathrm{m}, 15 \mu \mathrm{m}, 7 \mu \mathrm{m}, 10$ $\mu \mathrm{m}, 20 \mu \mathrm{m}$ and $70 \mu \mathrm{m}$, respectively. The $20 \mu \varepsilon$ deviation from linearity definition to the stress- strain response (Figure 4f) led to a composite modulus of $105.2 \pm 2 \mathrm{GPa}$. 


$$
\begin{gathered}
\mathrm{E}_{\text {multilayer }}=\left(\mathrm{t}_{1} / \mathrm{t}\right) \mathrm{E}_{\text {Substrate }}+\left(\mathrm{t}_{2} / \mathrm{t}\right) \mathrm{E}_{\mathrm{PAB}}+\cdots\left(\mathrm{t}_{6} / \mathrm{t}\right) \mathrm{E}_{\text {Cathode }}+\left(\mathrm{t}_{7} / \mathrm{t}\right) \mathrm{E}_{\mathrm{CCC}} \\
\mathrm{E}_{\mathrm{CCC}}=127.5 \mathrm{GPa}
\end{gathered}
$$

It should be noted here that in each step of the calculation, an average modulus of the composite specimen (Table 1) was used to calculate the average in-situ Young's moduli of functional layers (Table 3). The use of outlier values for composite modulus would lead to additional error propagation in every step with cumulative error [37]. An approach for estimation of the error in the calculation of the Young's modulus for each layer in the multilayer along with the associated assumptions is presented in Appendix A.

Table 3 includes the calculated in-situ Young's modulus (with the error estimate based on analysis in Appendix A) using microtensile testing. The Young's modulus determined from microtensile testing is compared to the corresponding values obtained by application of the nanoindentation technique on multilayer specimens and the RUS technique on bulk specimens made with a porosity and composition similar to the layers themselves. These values suggest that the Young's modulus values obtained using the proposed experimental procedure were in all cases (except for the anode) close to the corresponding Young's modulus values obtained using the RUS technique. The Young's modulus values obtained using microtensile testing were, however, found to be different from the corresponding values obtained by nanoindentation on the various layers. For example, in the case of MMA substrate, nanoindentation yielded a much higher value of $250 \pm 0.2 \mathrm{GPa}$ as compared to $70 \pm 1.0 \mathrm{GPa}$ with the microtensile testing technique. Such high value of Young's modulus, in the case of nanoindentation, is obtained due to indentation on individual grains of the spinel or periclase phase and was confirmed from optical micrographs (Figure 5). The indentation deformation field can also interact with adjacent 
layers leading to additional errors. For example, the average Young's modulus of electrolyte material $(6 \mathrm{ScSZ})$ from nanoindentation is 69.8 , GPa a much lower value than the $225.8 \mathrm{GPa}$ obtained by microtensile testing, and the latter value is closer to the expected Young's modulus for this material. It could therefore, be concluded that in the case of porous and/or microcracked ceramic materials, the Young's modulus values obtained using the nanoindentation technique are affected by the local microstructural features in the material i.e. grains, grain boundaries, microcracks, porosity etc., and therefore, should be interpreted with caution. The reasons for discrepancy in the Young's modulus values measured by tensile testing and RUS methodologies have been discussed in detail in a recent paper [7]. For a multilayer specimen, however, there are additional variables and the reason for the discrepancy in the values of the Young's modulus measured by microtensile and RUS testing are likely related to the porosity and interfacial properties of individual layers. For example, there could be severe differences in the defect distribution (e.g. porosity) of the anode thin layer and the corresponding bulk RUS specimen. It is, however, noted that the Young's modulus value of the unreduced anode determined by microtensile testing is closer to the value reported in the literature [56]. The procedure outlined in this manuscript could be extended for in-operando experiments at elevated temperature and could be used to calculate the residual stresses formed in the individual layers during cooling from the processing temperature of the SOFC stack. Finally, the outlined methodology can also be applied for other functional multilayer systems.

\section{CONCLUSIONS}

An improved experimental methodology was implemented to measure the in-situ Young's modulus of the substrate and constituent ceramic layers of a substrate supported SOFC. 
The methodology required the fabrication of a series of multilayer ceramic specimens. In addition, microtensile testing was performed on specimens fabricated from the MMA substrate and additional screen printed multilayer specimens that constitute a solid oxide fuel cell. The measured in-plane strain on both sides of multilayer specimens provided a means to ensure the validity of the equistrain criterion that was applied to calculate the Young's modulus of individual layers. The values of Young's modulus obtained from the proposed new methodology were close to the corresponding values obtained on bulk specimens using the resonant ultrasound spectroscopy (RUS) technique but different from the Young's modulus values determined on similar specimens by the nanoindentation technique. In addition to the Young's modulus value of the individual layers, a simplified procedure to determine the error in determined Young's modulus of the individual layers with the above methodology was presented.

\section{ACKNOWLEDGEMENTS}

This research is based upon work supported by the U.S. Department of Energy (Office of Fossil Energy), National Energy Technology Laboratory under Award Number DE-FE0000303. The

authors thank R. Trejo, D. McClurg, R. Lowden and A. Marquez for assistance with nanoindentation and RUS experiments. T. R. Watkins, D. Erdman and E. Lara-Curzio are thanked for reviewing the manuscript.

\section{DISCLAIMER}

This report was prepared as an account of work sponsored by an agency of the United States Government. Neither the United States government nor any agency thereof, nor any of their 
employees, makes any warranty, express or implied, or assumes any legal liability or responsibility for the accuracy, completeness or usefulness of any information, apparatus, product, or process disclosed, or represents that its use would not infringe privately owned rights. Reference herein to any specific commercial product, process, or service by trade name, trademark, manufacturer, or otherwise does not necessarily constitute or imply its endorsement, recommendation, or favoring by the United States Government or any agency thereof. The views and opinions of the authors expressed herein do not necessarily state or reflect those of the United States Government, any agency thereof, or LG Fuel Cell Systems Inc. 


\section{APPENDIX 1}

In summation notation, the Young's Modulus of the multilayer can be written as:

$E_{\text {multilayer }}=\sum_{i=1}^{n} \frac{t_{i}}{t} E_{i}$

where, $t_{i}$ is the thickness of layer $i$ and other terms have been introduced earlier. Using error propagation rules, the following expression can be derived for the error in the Young's modulus of the multilayer:

$\Delta E_{\text {multilayer }}=\sum_{i=1}^{n} \frac{t_{i}}{t} E_{i}\left\{\frac{\Delta t_{i}}{t_{i}}+\frac{\Delta t}{t}+\frac{\Delta E_{i}}{E_{i}}\right\} \ldots \ldots$

In this expression, if all the error terms are known or can be estimated after every multilayer test, the $\Delta E_{\text {multilayer }}$ can be estimated for the individual tests as well. Unfortunately, the errors in $\mathrm{t}_{\mathrm{i}}$, $\mathrm{t}$ and $\mathrm{E}_{\mathrm{i}}$ are interdependent and estimating them individually leads to an overestimate in the total error. In order to estimate the total error in the multilayer, a probabilistic Monte Carlo simulation [57] needs to be performed which is beyond the scope of this manuscript. A simplified procedure is presented below to estimate the error in the calculation of the modulus values. In this procedure, the multilayer is imagined as a bilayer consisting of layer ' $\mathrm{i}$ ' and another layer comprising layers 1 to (i-1). With this simplification, Equation A2 can be rewritten as:

$\Delta E_{\text {multilayer }}=\frac{t_{1, i-1}}{t} E_{1, i-1}\left\{\frac{\Delta t_{1, i-1}}{t_{1, i-1}}+\frac{\Delta t}{t}+\frac{\Delta E_{1, i-1}}{E_{1, i-1}}\right\}+\frac{t_{i}}{t} E_{i}\left\{\frac{\Delta t_{i}}{t_{i}}+\frac{\Delta t}{t}+\frac{\Delta E_{i}}{E_{i}}\right\} \ldots \ldots$

where, the terms with subscript $(1, i-1)$ corresponds to properties of all but the $i^{\text {th }}$ layer and the latter is denoted by subscript $(i)$. For calculations associated with the layer consisting of $(1, i-1)$ layers, it was assumed that error in modulus measurement was $2.5 \%$ and for all conditions the 
total error in thickness measurement was assumed to be $0.4 \%$, i.e. $\frac{\Delta t_{1, i-1}}{t_{1, i-1}}+\frac{\Delta t}{t}=\frac{\Delta t_{i}}{t_{i}}+\frac{\Delta t}{t}=0.004$ and $\frac{\Delta E_{1, i-1}}{E_{1, i-1}}=0.025$. Assuming higher errors would lead to a negative $\Delta \mathrm{E}_{\text {multilayer }}$ which will be physically unrealistic. Since all the terms are known in Equation A3, inputting the experimentally determined error in the modulus of the multilayer, which is the error in the modulus value of the composite in Table 1, will give the error in the calculated modulus of the individual layer, $\Delta \mathrm{E}_{i}$. This procedure was applied for all the layers and in this manner, the $E_{i} \pm \Delta E_{i}$ values are reported in Table 3 


\section{REFERENCES}

1. E. Wachsman, A. Marlowe, K. Lee, Energy Env. Sci. 5 (2012) 5498-5509.

2. A.B. Stambouli, E Traversa. Renew Sustainable Energy Rev. 6 (2002) 433-455.

3. A. Choudhury, H. Chandra, A. Arora. Renewable and Sustainable Energy Rev. 20 (2013) $430-442$.

4. S.C. Singhal, Solid State Ionics 135 (2000) 305-313.

5. A. Bertei, C. Nicolella, J. Power Sources 196 (2011) 9429- 9436.

6. A. Bertei, A.Barbucci, M. P. Carpanese, M. Viviani, C. Nicolella, Chemical Eng. J. 207208 (2012) 167-174.

7. A. Pandey, A. Shyam, T R. Watkins, E. Lara-Curzio, R. J. Stafford. K. J. Hemker, J. Am. Ceram. Soc. 97 (2014) 899- 906.

8. D.T. Hristopulos, M. Demertzi, J. Eur. Ceram. Soc. 28 (2008) 1111-1120.

9. A. Atkinson, P. Bastid, Q. Liu, J. Am. Ceram. Soc. 90 (2007) 2489-2496.

10. G. Bruno, A.M. Efremov, A.N. Levandovskiy, B. Clausen, J. Mater. Sci. 46 (2011) 161173.

11. G. Bruno, A.M. Efremov, A.N. Levandovskiy, I. Pozdnyakova, D.J. Hughes, B. Clausen, Mat. Sci. Forum 652 (2010) 191-196.

12. M. Morales, J.J. Roa, X.G. Capdevila, M. Segarra, S. Piñol, Acta Mater. 58 (2010) 25042509.

13. A. K. Sleiti, J. Power Sources 195 (2010) 5719-5725.

14. Y.C. Yang, T.H. Chang, Y.C. Wu, S.F. Wang, Int. J. Hydrogen Energy 37 (2012) 1374613754. 
15. A. Nakajo, F. Mueller, J. Brouwer, J. V. Herle, D. Favrat, Int. J. Hydrogen Energy 37 (2012) 9249-9268.

16. L.K. Chiang, H.C. Liu, Y. H. Shiu, C. H. Lee, R.Y. Lee, Renewable Energy 33 (2008) 2580-2588.

17. C. K. Lin, T. T. Chen, Y. P. Chyou, L. K. Chiang, J. Power Sources 164 (2007) 238-251.

18. K.S. Weil, B.J. Koeppel, Int. J. Hydrogen Energy 33 (2008) 3976-3990.

19. Z. Peng, J. Gong, H. Miao, J. Eur. Ceram. Soc. 24 (2004) 2193-2201.

20. R. Clague, A.J. Marquis, N.P. Brandon, J. of Power Sources 221 (2013) 290-299.

21. O. Razbani, I. Wærnhus, M. Assadi, Applied Energy 105 (2013) 155-160.

22. A. Nakajo, Z. Wuillemin, J. Van Herle, D. Favrat, J. of Power Sources 193 (2009) 203215.

23. R. Clague, A.J. Marquis, N.P. Brandon, J. of Power Sources 210 (2012) 224-232.

24. D. Jauffrès, C. Yacou, M. Verdier, R. Dendievel, A. Ayral, Microporous and Mesoporous Mat. 140 (2011) 120-129.

25. B. K. Jang, H. Matsubara, Mat. Lett. 59 (2005) 3462-3466.

26. X. Chen, Y. Xiang, J. J. Vlassak, J. of Mat. Res. 21 (2006) 715-724.

27. C. Eberl, D.S. Gianola, X. Wang, M.Y. He, A.G. Evans, K.J. Hemker, 59 (2011) Acta Mater., 3612-3620.

28. F. J. Gardner, M. J. Day, N. P. Brandon, M. N. Pashley, M. Cassidy, J. Power Sources 86 (2000) 122-129.

29. A Shyam, E Lara-Curzio, T. R. Watkins, R. J. Parten, J. Am. Ceram. Soc. 91 (2008) 1995- 2001. 
30. A. Shyam, E. Lara-Curzio, A. Pandey, T. R. Watkins, K. L. More, J. Am. Ceram. Soc. 95 (2012) 1682- 1691.

31. C. Eberl, R. Thompson, D. Gianola "Digital image correlation and tracking with Matlab. User guide. Published on Matlab Central file Exchange" (2006).

32. A. Pandey, V. K. Tolpygo, K.J. Hemker, JOM, 65 (2013) 542- 549.

33. W.C. Oliver, G.M. Pharr, J. Mat. Res., 7 (1992) 1564-1583.

34. M. Borba, M. D. de Araújo, E. de Lima, H. N. Yoshimura, P. F. Cesar, J. A. Griggs, Á. D. Bona, Dental Mat., 27 (2011) 1259-1266.

35. X. Chen, S. Wu, J. Zhou, Constr. Build. Mater. 40 (2013) 869-874.

36. X. Deng, N. Chawla, K.K. Chawla, M. Koopman, J.P. Chu, Adv. Eng. Mat. 7 (2005) 1099.

37. P. Hollman, M. Larsson, P. Hedenqvist, S. Hogmark, Surface and Coatings Tech., 90 (1997) 234-238.

38. K.A Khor, Y.W Gu, Z.L Dong, Surf. Coat. Tech. 139 (2001) 200-206.

39. M. Nie, Q.A. Huang, W.H. Li, H. Rong, Transducers, (2005) 836-839.

40. M. Kot, W.A. Rakowski, Ł. Major, R. Major, J. Morgiel, Surf. Coat. Tech. 202 (2008) 3501-3506.

41. T.A. Rawdanowicz, V. Godbole, J. Narayan, J. Sankar, A. Sharma, Comp. Part B: Eng. 30 (1999) 657-665.

42. A. Ohtsuki, Proc. Eng. 10 (2011) 1041-1046.

43. J.-Y. Chang, G.-P. Yu, J. -H. Huang, Thin Solid Films 517 (2009) 6759-6766.

44. H. Y. Chen, C. J. Tsai, F. H. Lu, Surf. Coat. Tech.184 (2004) 69-73.

45. J. Matejicek, S. Sampath, Acta Mater. 51 (2003) 863- 872. 
46. M. D. Tran, J. Poublan, J. H. Dautzenberg, Thin Solid Films 308 (1997) 310-314.

47. W. Araki, H. Azuma, T. Yota, Y. Arai, J. Malzbender. Fuel Cells 13 (2013) 542-548.

48. X. Feng, Y. Huang, and A. J. Rosakis, Trans. ASME, 51 (2007) 1276- 1281.

49. J. Malzbender, R.W. Steinbrech, Surf. Coat. Tech. 176 (2004) 165-172.

50. D. Hull, T. W. Clyne. Cambridge Univ. press, 1996.

51. C-H. Hsueh, J. Am. Ceram. Soc. 74 (1991) 1646-1649.

52. C-H. Hsueh, J. Appl. Phys. 91 (2002) 9652- 9656.

53. R. J. Stafford, K. B. Golovin, A. Dickinson, T. R. Watkins, A. Shyam, E. Lara-Curzio, Adv. Bioceram. Porous Ceram. V (2012) 197-203.

54. A. Atkinson, P. Bastid, and Q. Liu, J. Am. Ceram. Soc. 90 (2007) 2489-2496.

55. A. Wereszczak, E. Fox, M. Lance, M. Ferber, SAE Int. J. Mater. Manuf. 5 (2012) 517527.

56. M. Radovic, E. Lara-Curzio, Acta Mater. 52 (2004) 5747-5756.

57. S. H. Lee, W. Chen, Struct. Multidisc. Optim. 37 (2009) 239-253. 


\section{Table Caption}

Table 1: List of screen-printed multilayer specimen types and their composite moduli.

Table 2: Existing experimental techniques used to study the elastic properties of multilayer structures.

Table 3: Comparison of in-situ Young's modulus obtained using microtensile testing, nanoindentation on thin layers and the RUS technique on the corresponding bulk specimens. 
Table 1

\begin{tabular}{|c|c|c|c|c|c|}
\hline $\begin{array}{c}\text { Multilayer Ceramic } \\
\text { Specimen }\end{array}$ & $\begin{array}{c}\text { No of } \\
\text { layers } \\
\text { (excluding } \\
\text { substrate) }\end{array}$ & $\begin{array}{l}\text { In- } \\
\text { plane } \\
\text { layers }\end{array}$ & $\begin{array}{c}\text { Net thickness of } \\
\text { Substrate }+ \text { average } \\
\text { thickness of active } \\
\text { layers } \\
\text { (Total thickness of } \\
\text { ceramic composite } \\
\text { layers } \sim 190 \pm 5 \mu \mathrm{m}) \\
\end{array}$ & $\begin{array}{c}\text { Figure } \\
\text { no\# }\end{array}$ & 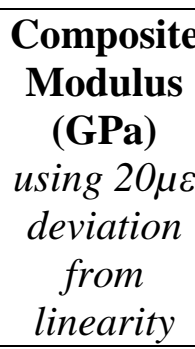 \\
\hline Substrate only (S) & 0 & $\mathrm{~S}$ & $\begin{array}{c}190,170,150,130,100, \\
50\end{array}$ & 4 & $70 \pm 1$ \\
\hline $\begin{array}{c}\text { Substrate }(\mathrm{S})+\text { Porous } \\
\text { anode barrier (PAB) }\end{array}$ & 1 & $\begin{array}{l}\text { S \& } \\
\text { PAB }\end{array}$ & $165+25$ & $4 a$ & $69 \pm 2$ \\
\hline $\begin{array}{c}\text { Substrate }(\mathrm{S})+\text { Porous } \\
\text { anode barrier }(\mathrm{PAB})+ \\
\text { Anode current collector } \\
(\mathrm{ACC})\end{array}$ & 2 & $\begin{array}{c}\mathrm{S} \& \\
\mathrm{ACC}\end{array}$ & $150+25+15$ & $4 b$ & $71 \pm 4$ \\
\hline $\begin{array}{c}\text { Substrate }(\mathrm{S})+\text { Porous } \\
\text { anode barrier }(\mathrm{PAB})+ \\
\text { Anode current collector } \\
(\mathrm{ACC})+\mathrm{Anode}(\mathrm{A})\end{array}$ & 3 & S \& A & $143+25+15+7$ & $4 \mathrm{c}$ & $71 \pm 3$ \\
\hline $\begin{array}{l}\text { Substrate }(\mathrm{S})+\text { Porous } \\
\text { anode barrier (PAB)+ } \\
\text { Anode current collector } \\
\text { (ACC)+Anode }(\mathrm{A})+ \\
\text { Electrolyte }(\mathrm{E})\end{array}$ & 4 & $\mathrm{~S} \& \mathrm{E}$ & $133+25+15+7+10$ & $4 d$ & $79 \pm 2$ \\
\hline $\begin{array}{l}\text { Substrate }(\mathrm{S})+\text { Porous } \\
\text { anode barrier }(\mathrm{PAB})+ \\
\text { Anode current collector } \\
(\mathrm{ACC})+\text { Anode }(\mathrm{A})+ \\
\text { Electrolyte }(\mathrm{E})+ \\
\text { Cathode }(\mathrm{C})\end{array}$ & 5 & $\mathrm{~S} \& \mathrm{C}$ & $113+25+15+7+10+20$ & $4 \mathrm{e}$ & $84 \pm 3$ \\
\hline $\begin{array}{l}\text { Substrate }(\mathrm{S})+\text { Porous } \\
\text { anode barrier }(\mathrm{PAB})+ \\
\text { Anode current collector } \\
(\mathrm{ACC})+\text { Anode }(\mathrm{A})+ \\
\text { Electrolyte }(\mathrm{E})+ \\
\text { Cathode }(\mathrm{C})+\text { Cathode } \\
\text { current collector }(\mathrm{CCC})\end{array}$ & 6 & $\begin{array}{l}\mathrm{S} \& \\
\mathrm{CCC}\end{array}$ & $43+25+15+7+10+20+70$ & $4 \mathrm{f}$ & $105 \pm 2$ \\
\hline
\end{tabular}


Table 2

\begin{tabular}{|c|c|c|}
\hline Layers/ Materials & Techniques & Reference \# \\
\hline $\begin{array}{l}\text { Thermal barrier coating } \\
\text { (Bilayer beam, TopCoat/Bond } \\
\text { Coat) }\end{array}$ & $\begin{array}{l}\text { Micro flexure testing and } \\
\text { composite beam theory }\end{array}$ & Eberl et al., 2011 [27] \\
\hline $\begin{array}{l}\text { Bi and tri layer ceramic } \\
\text { structures }\end{array}$ & $\begin{array}{l}\text { Flexural testing and composite } \\
\text { beam theory }\end{array}$ & Borba et al., 2011 [34] \\
\hline Thin film and Coatings & Uniaxial Tension & $\begin{array}{c}\text { Pandey et al., } 2013 \text { [32], } \\
\text { Deng et al., [36], Hollman et } \\
\text { al., 1997 [36] }\end{array}$ \\
\hline $\begin{array}{l}\text { YSZ/NiCoCrAlY composite } \\
\text { coatings }\end{array}$ & $\begin{array}{l}\text { Four-point bending, composite } \\
\text { beam theory, rule of mixture }\end{array}$ & Khor et al., 2001 [38] \\
\hline Multilayer thin films & $\begin{array}{l}\text { Electrostatic pull-in test structure } \\
\text { and analytical modeling }\end{array}$ & Nie et al., 2005 [39] \\
\hline $\mathrm{Cr} / \mathrm{CrN}$ multilayer coatings & Microindentation & Kot et al., 2008 [40] \\
\hline AlN/TiN thin films & Nanoindentation & $\begin{array}{c}\text { Rawdanowicz et al., } 1999 \\
\text { [41] }\end{array}$ \\
\hline $\begin{array}{l}\text { Thin flexible multi-layered } \\
\text { material. }\end{array}$ & Compression Column Method & Ohtsuki, 2011 [42] \\
\hline Thin film and coatings & Diffraction and Curvature Method & $\begin{array}{l}\text { Chang et al., } 2009 \text { [43], Chen } \\
\text { et al., } 2004 \text { [44], Matejicek } \\
\text { and Sampath, } 2003 \text { [45], } \\
\text { Tran et al., } 1997 \text { [46] }\end{array}$ \\
\hline $\begin{array}{l}\mathrm{Bi} \text { and tri layer ceramic } \\
\text { structures }\end{array}$ & $\begin{array}{c}\text { Combination of FE and RUS } \\
\text { technique }\end{array}$ & Araki et al., 2013 [47] \\
\hline
\end{tabular}




\section{Table 3}

\begin{tabular}{|c|c|c|c|}
\hline Material (layer) & $\begin{array}{c}\text { E (GPa) } \\
\text { (tensile curves, } \\
\text { using } 20 \mu \varepsilon \\
\text { deviation from } \\
\text { linearity) } \\
\left(E_{i} \pm \Delta E_{i}\right)\end{array}$ & $\begin{array}{c}\text { E (GPa) } \\
\text { (nano- } \\
\text { indentation) }\end{array}$ & $\begin{array}{c}\text { E (GPa) } \\
\text { (bulk value } \\
\text { using } R U S)\end{array}$ \\
\hline Substrate only (S) & $\mathbf{7 0} \pm 1.0$ & $250 \pm 0.2$ & $72 \pm 2$ \\
\hline Porous anode barrier (PAB) & $66.2 \pm 1.5$ & $63 \pm 11$ & - \\
\hline Anode current collector (ACC) & $\mathbf{9 5 . 3} \pm 27.0$ & - & - \\
\hline Anode(A) NiO YSZ & $64.5 \pm 27.3$ & $66 \pm 6$ & $193 \pm 0.6$ \\
\hline Electrolyte $(\mathrm{E})$ & $225.8 \pm 0.04$ & $69 \pm 11$ & $208 \pm 0.6$ \\
\hline Cathode (C) & $112.7 \pm 8.6$ & $43 \pm 3$ & $143 \pm 2$ \\
\hline Cathode current collector (CCC) & $\mathbf{1 2 7 . 5} \pm 0.7$ & $43 \pm 2$ & $129 \pm 2.0$ \\
\hline
\end{tabular}




\section{Figure captions}

Figure 1: Schematic of substrate supported solid oxide fuel cell (SOFC). The substrate is a rectangular thick wall $(<1 \mathrm{~mm})$ MMA (magnesia-magnesium aluminate spinel) material that is extruded with channels for fuel flow. Starting from the porous anode barrier (PAB), subsequent functional layers were screen printed sequentially onto the MMA substrate.

Figure 2: Cross-sectional SEM micrograph of the substrate supported solid oxide fuel cell (SOFC).

Figure 3a: Monotonic uniaxial tensile stress-strain response of MMA substrate specimen.

Figure 3b: Loading-unloading and reloading response of MMA substrate specimens of different thickness under uniaxial tensile loading.

Figure 4a: Uniaxial monotonic tensile stress-strain response of bilayer specimen i.e. MMA substrate $(\mathrm{S})+$ Porous anode barrier $(\mathrm{PAB})$.

Figure 4b: Uniaxial monotonic tensile stress-strain response of trilayer specimen i.e. MMA substrate $(\mathrm{S})+$ Porous anode barrier $(\mathrm{PAB})+$ Anode current collector (ACC).

Figure 4c: Uniaxial monotonic tensile stress-strain response of multilayer specimen i.e. MMA substrate $(\mathrm{S})+$ Porous anode barrier $(\mathrm{PAB})+$ Anode current collector $(\mathrm{ACC})+$ Anode $(\mathrm{A})$.

Figure 4d: Uniaxial monotonic tensile stress-strain response of multilayer specimen i.e. MMA substrate $(\mathrm{S})+$ Porous anode barrier $(\mathrm{PAB})+$ Anode current collector $(\mathrm{ACC})+$ Anode $(\mathrm{A})+$ Electrolyte (E). 
Figure 4e: Uniaxial monotonic tensile stress-strain response of multilayer specimen i.e. MMA substrate $(\mathrm{S})+$ Porous anode barrier $(\mathrm{PAB})+$ Anode current collector $(\mathrm{ACC})+$ Anode $(\mathrm{A})+$ Electrolyte (E) + Cathode (C).

Figure 4f: Uniaxial monotonic tensile stress-strain response of multilayer specimen i.e. MMA substrate $(\mathrm{S})+$ Porous anode barrier $(\mathrm{PAB})+$ Anode current collector $(\mathrm{ACC})+$ Anode $(\mathrm{A})+$ Electrolyte (E) + Cathode (C) + Cathode current collector (CCC)

Figure 5: Optical micrograph of typical nano indentation imprints on various layers in a substrate supported solid oxide fuel cell (SOFC). 


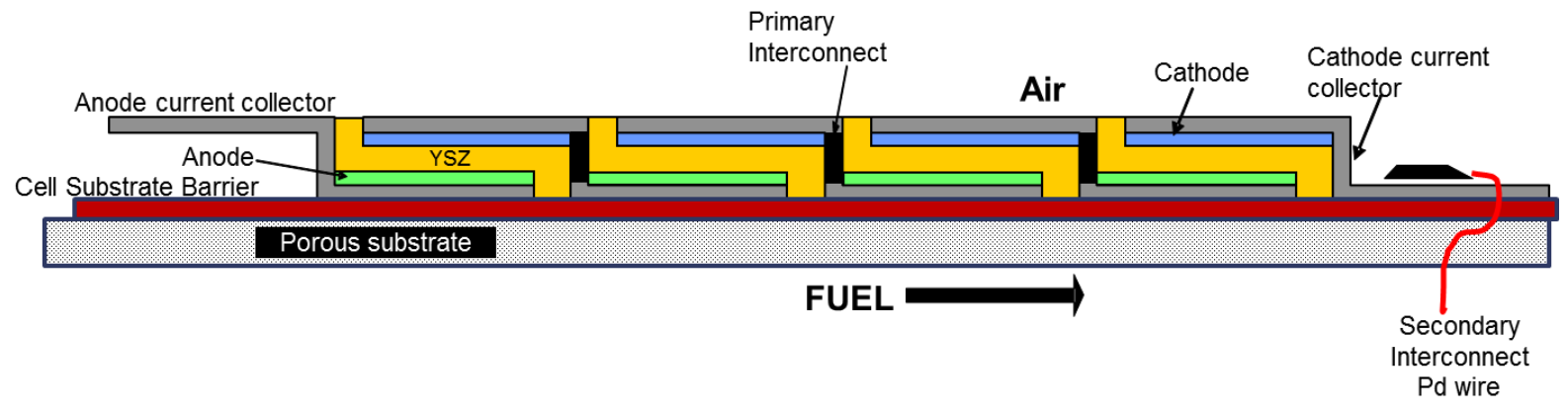

Figure 1 


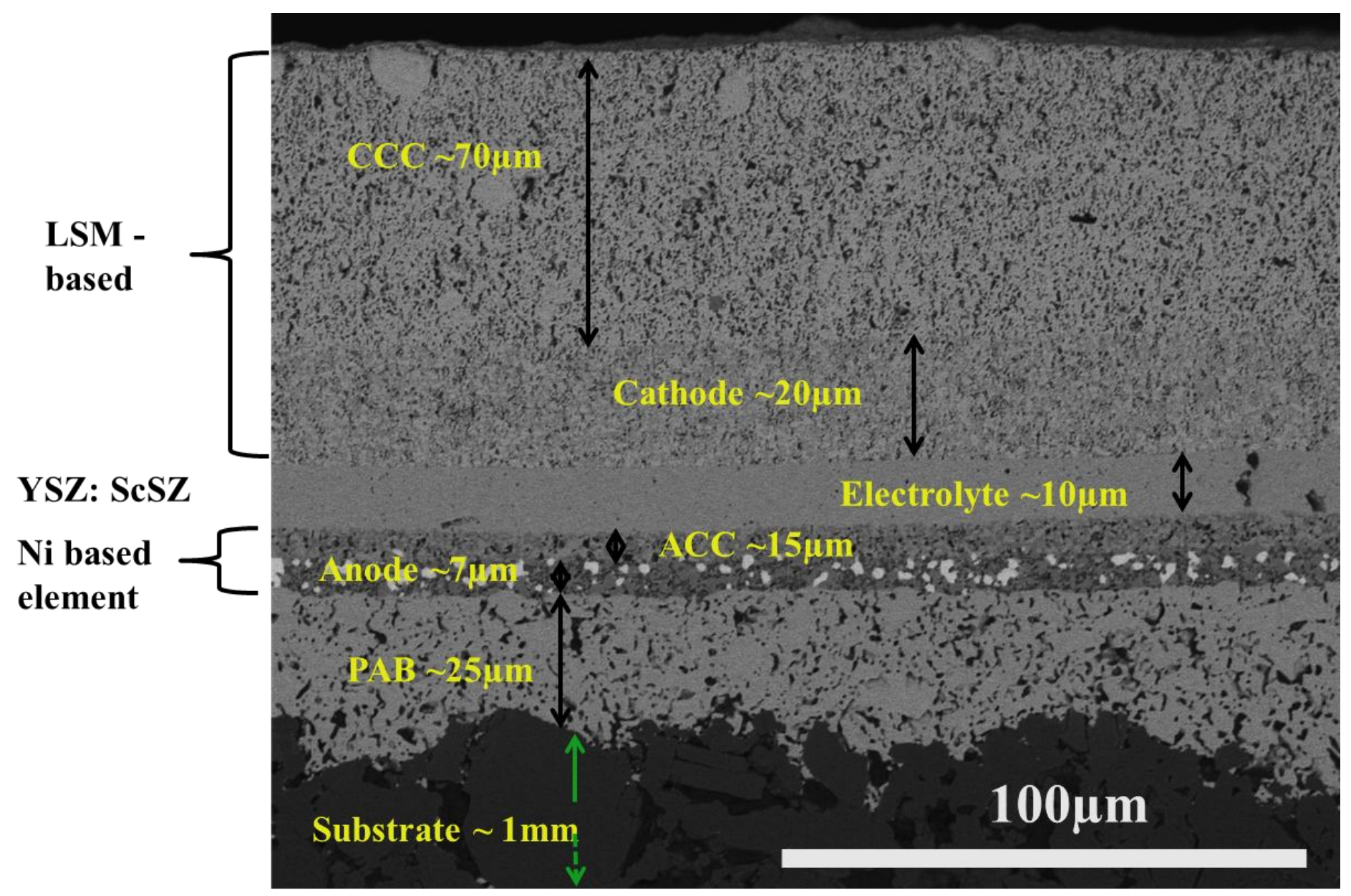

Figure 2 


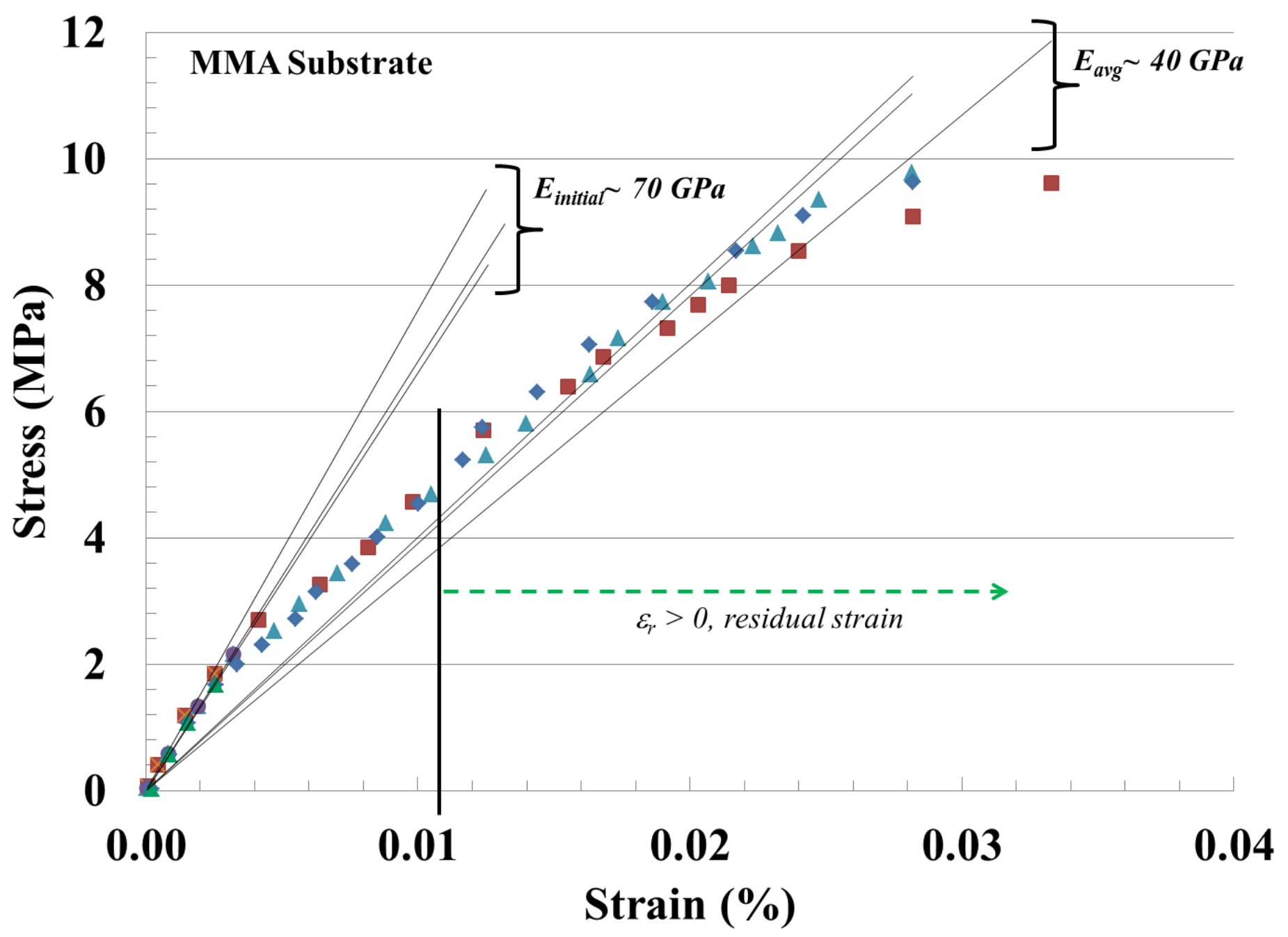

Figure 3a 


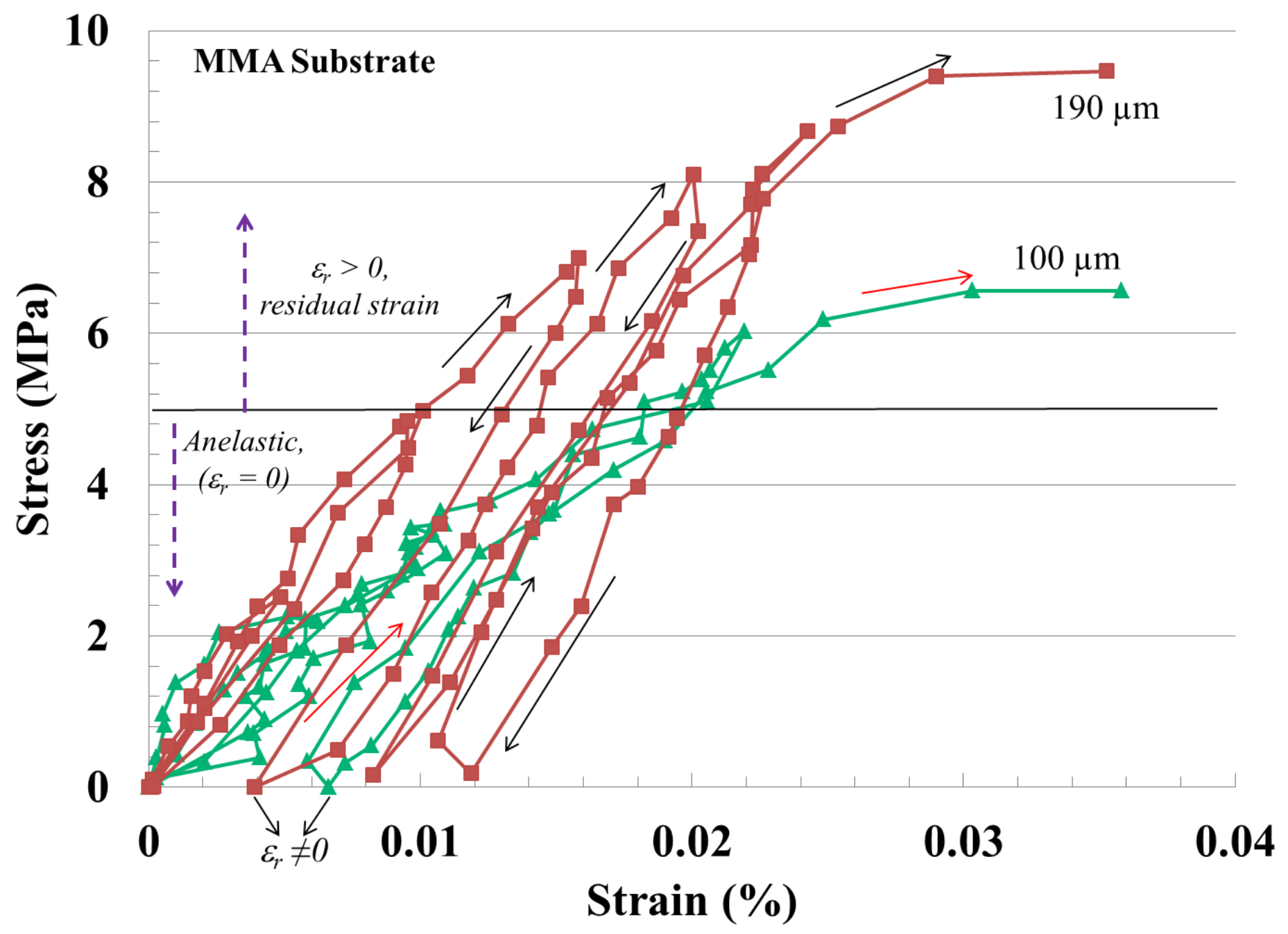

Figure 3b 


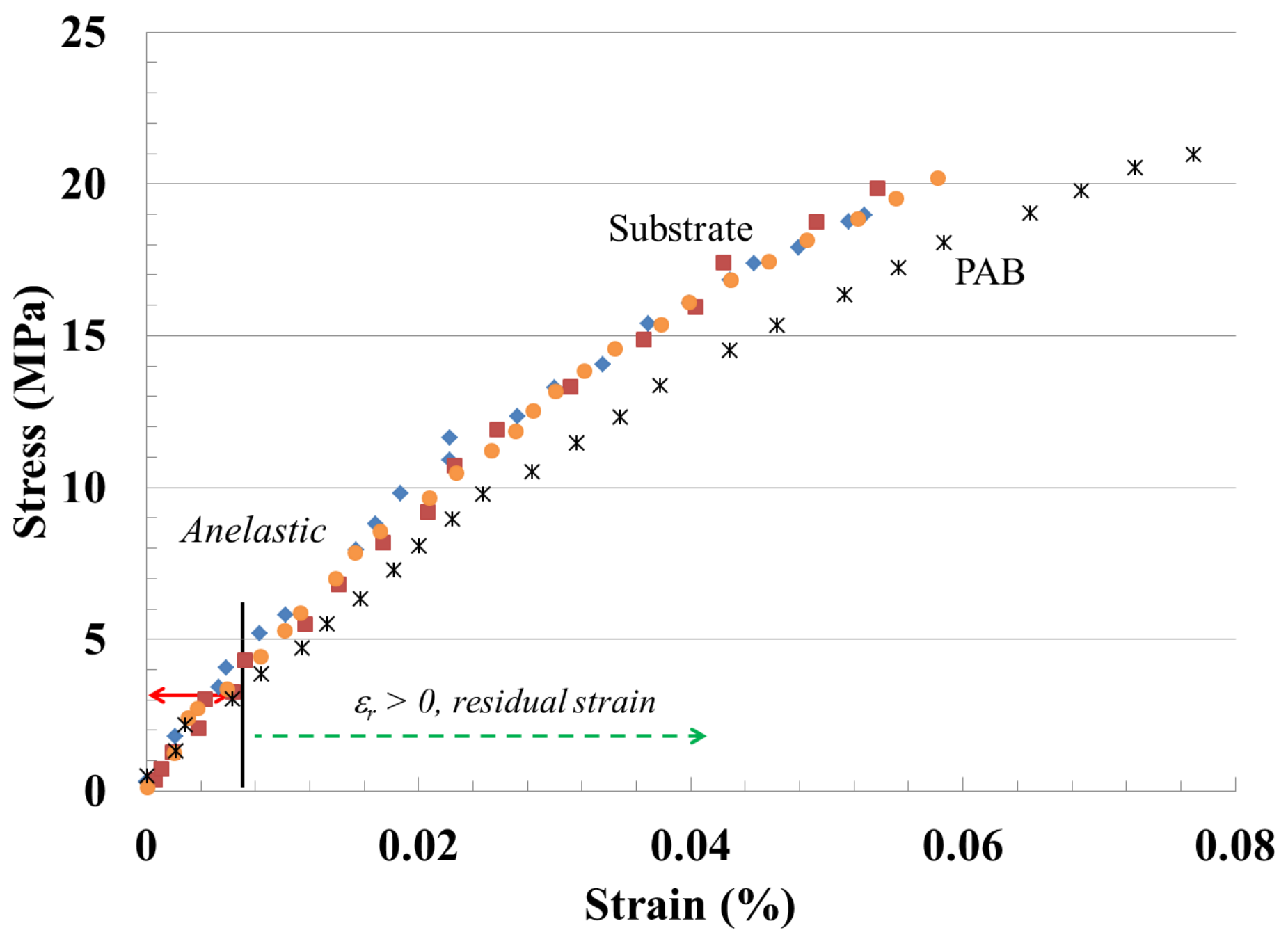

Figure 4a 


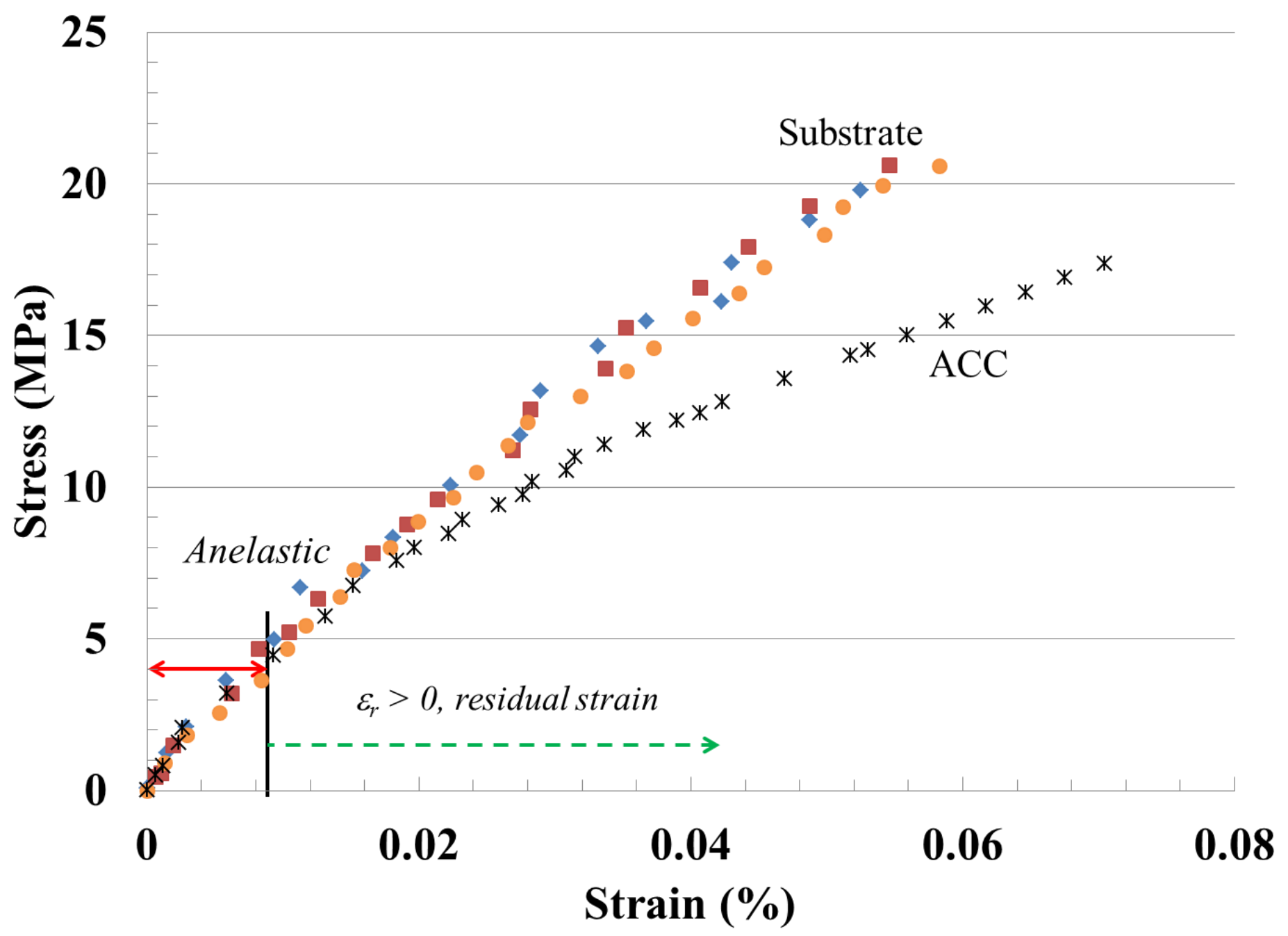

Figure 4b 


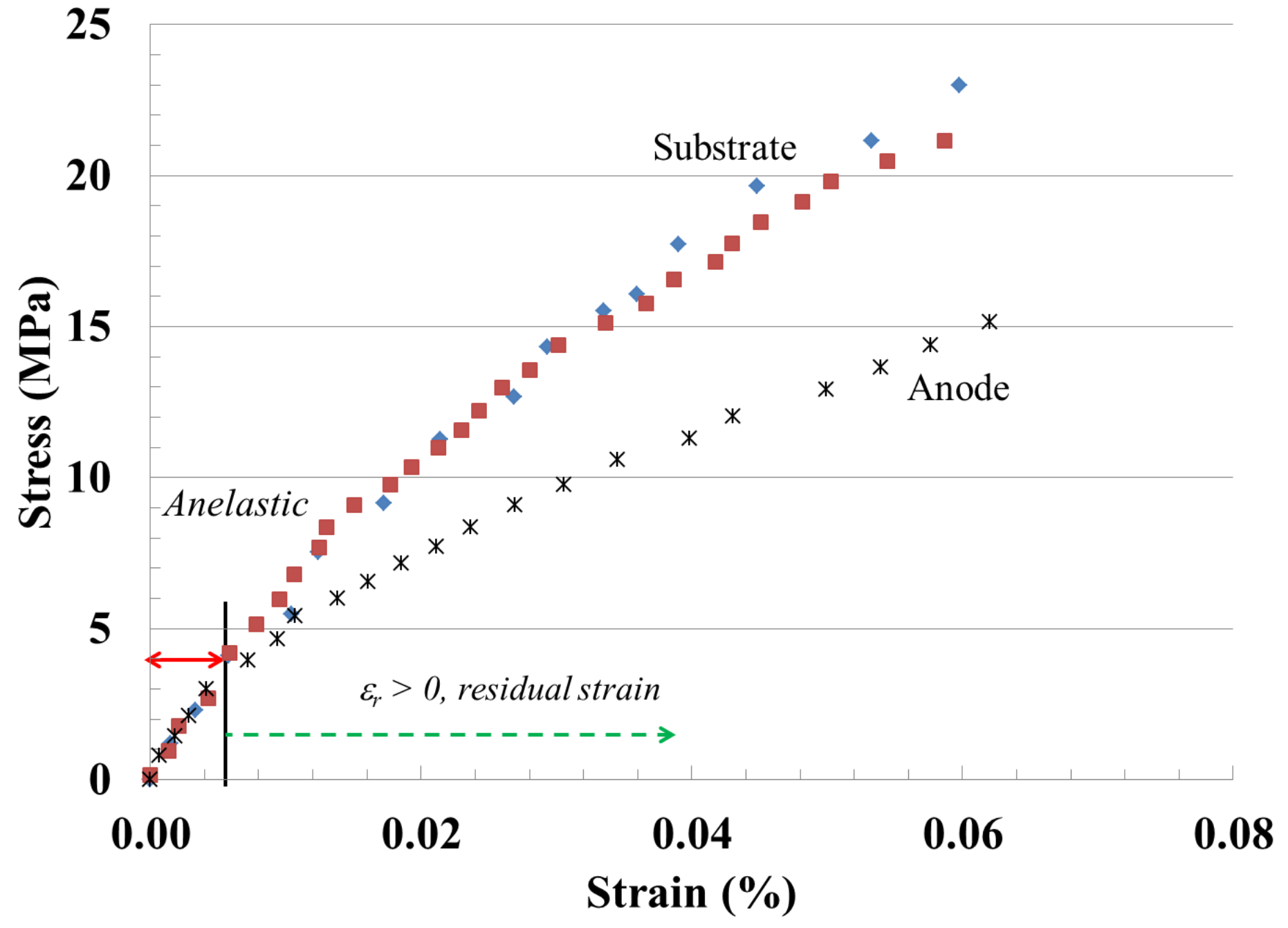

Figure 4c 


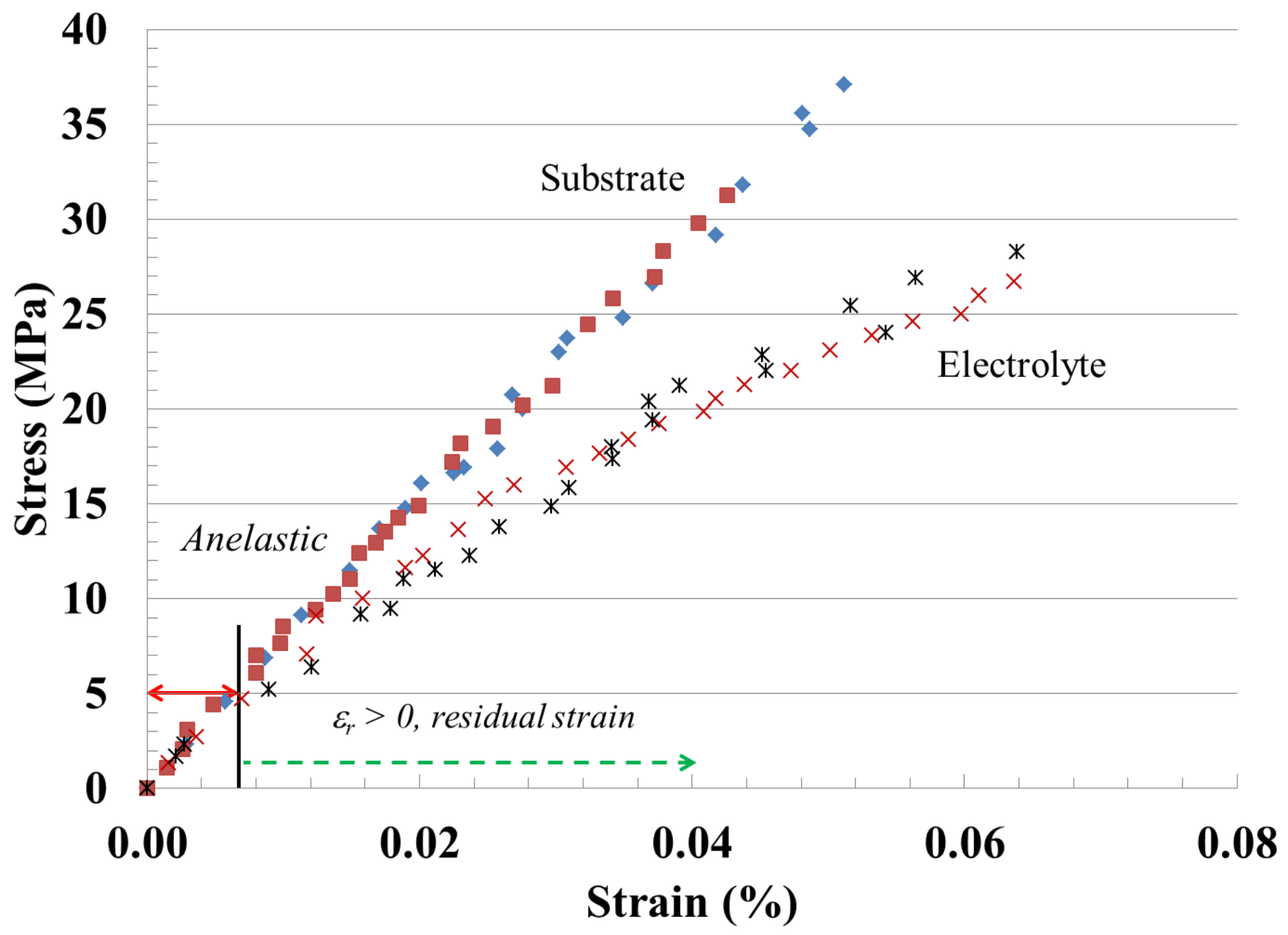

Figure 4d 


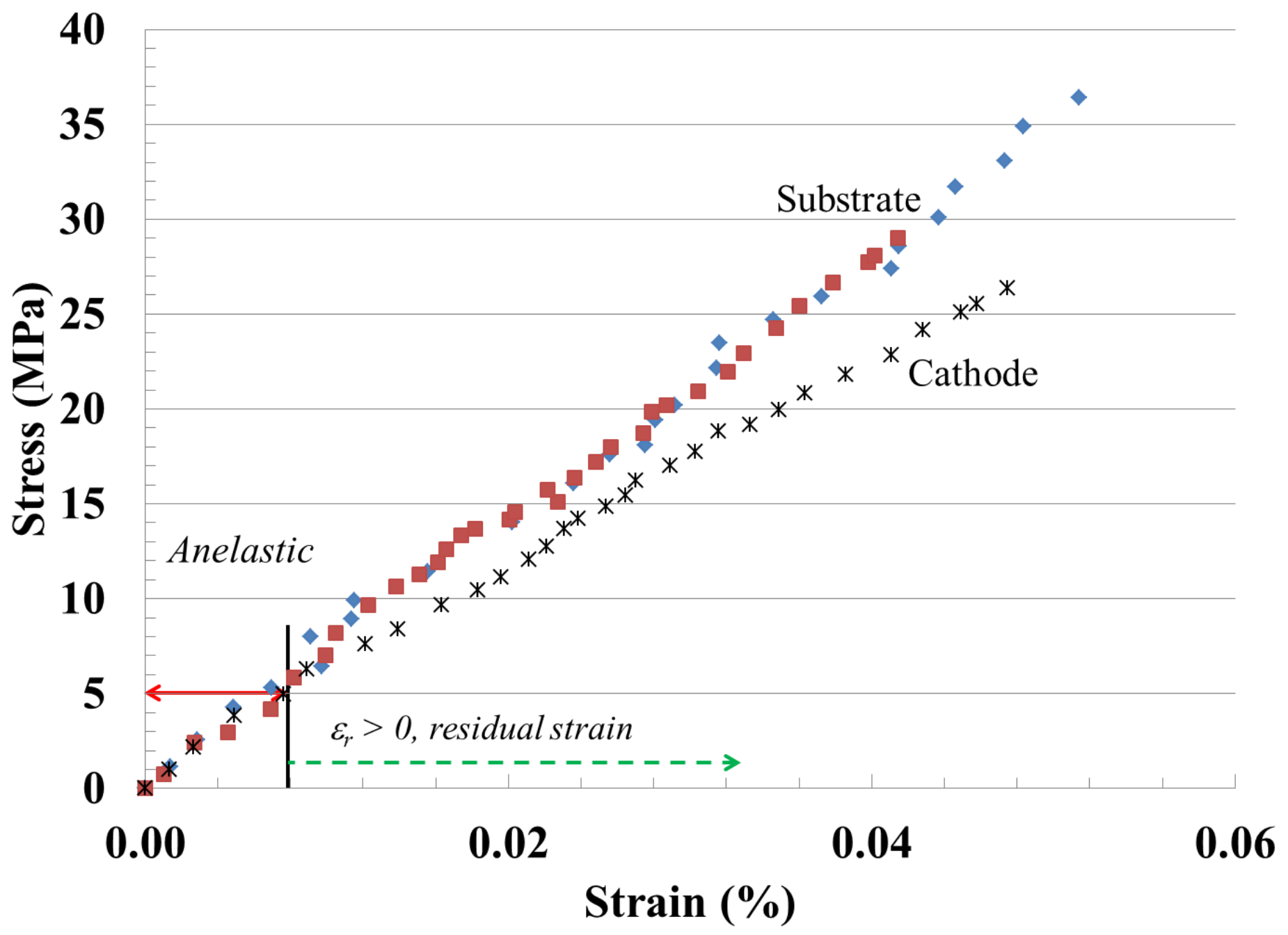

Figure 4e 


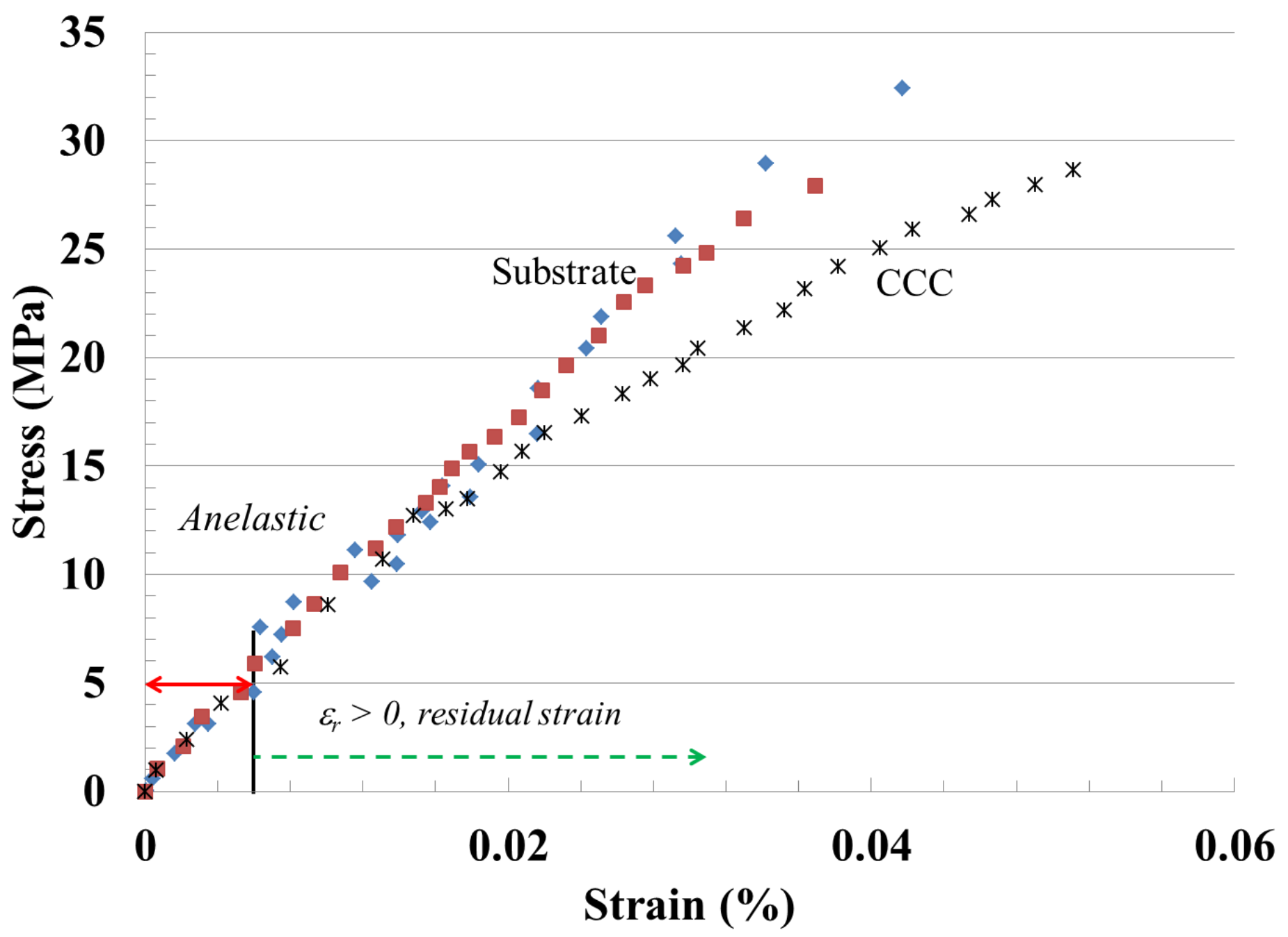

Figure 4f 


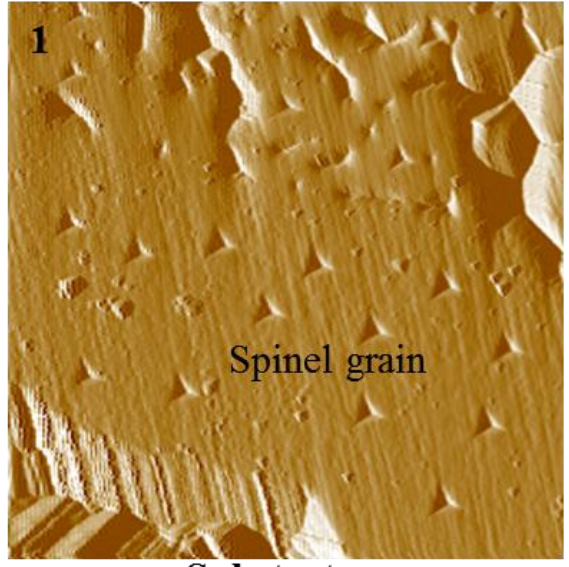

Substrate

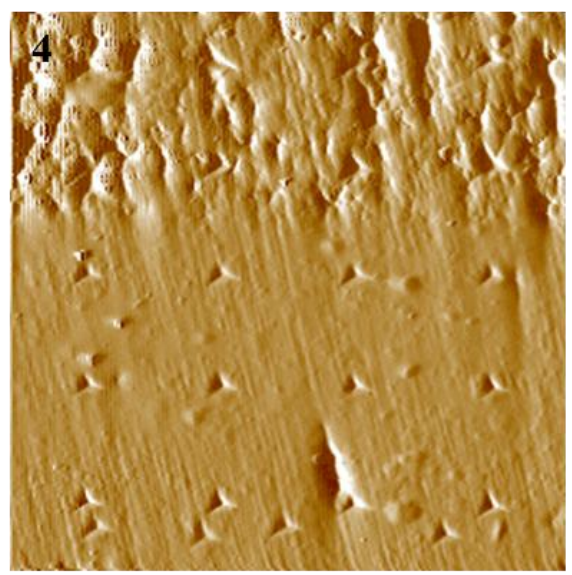

Electrolyte

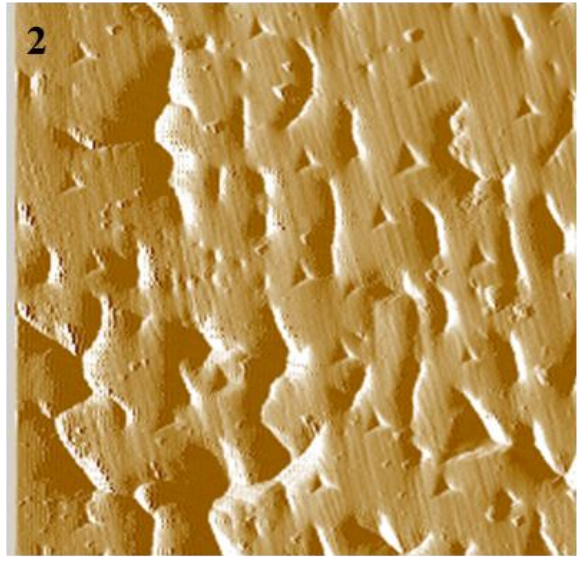

PAB

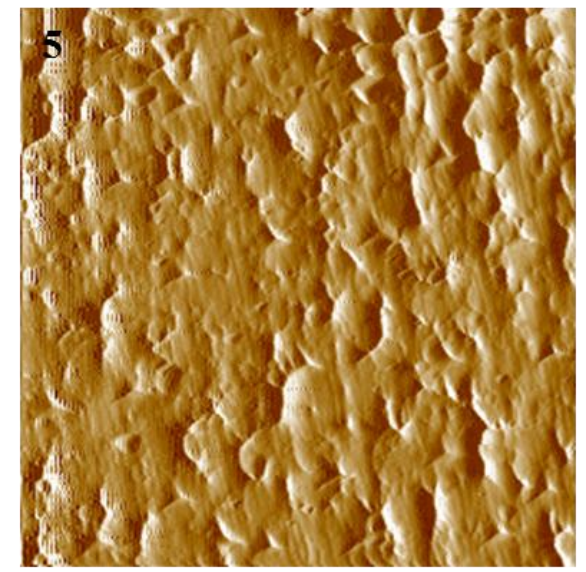

Cathode

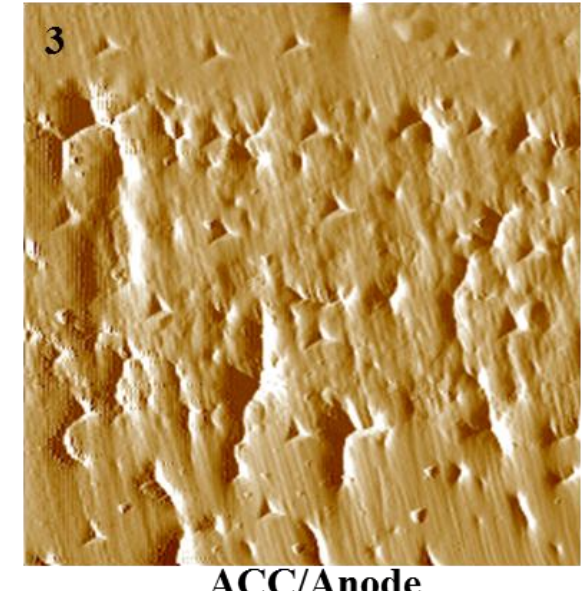

ACC/Anode

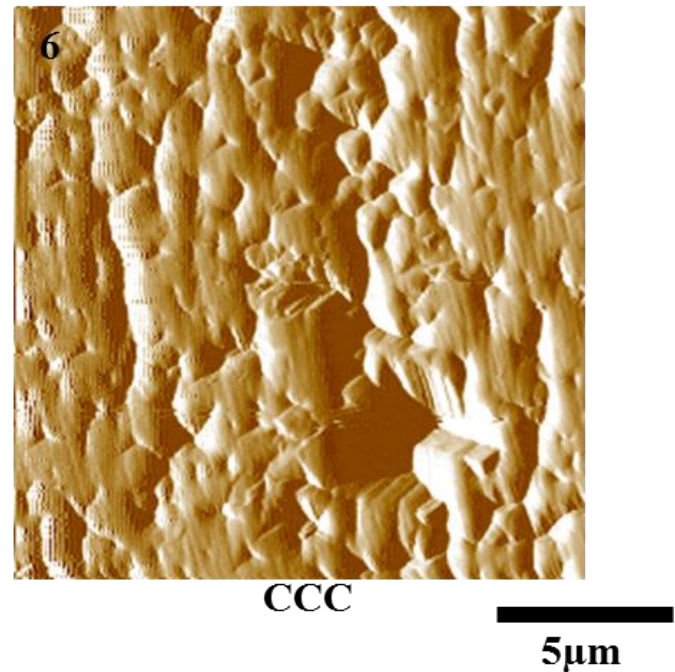

Figure 5 